\title{
Criteria to evaluate the quality of alginate wound dressings
}

\author{
Critérios para avaliação da qualidade de coberturas de alginato no tratamento de feridas \\ Criterios para evaluación de la calidad de coberturas de alginato en tratamiento de heridas
}

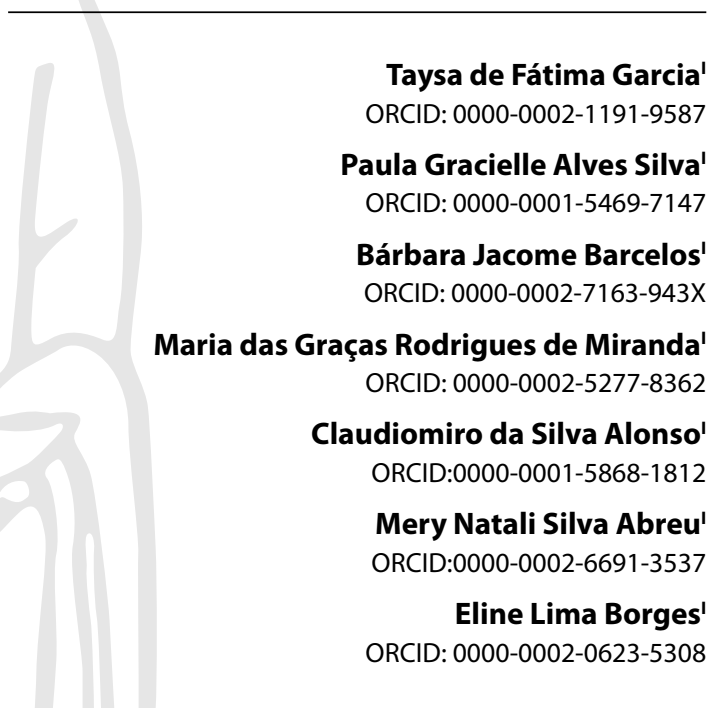

'Universidade Federal de Minas Gerais. Belo Horizonte, Minas Gerais, Brazil.

How to cite this article: Garcia TF, Silva PGA, Barcelos BJ, Miranda MGR, Alonso CS, Abreu MNS, et al. Criteria to evaluate the quality of alginate wound dressings. Rev Bras Enferm. 2021;74(4):e20201091. https://doi.org/10.1590/0034-7167-2020-1091

\section{Corresponding author:}

Taysa de Fátima Garcia E-mail: taysafati@hotmail.com

EDITOR IN CHIEF: Dulce Barbosa ASSOCIATE EDITOR: Fátima Helena Espírito Santo

\section{ABSTRACT}

Objectives: to validate an instrument with criteria to evaluate the quality of calcium alginate wound dressings to treat skin injuries. Methods: methodological study, developed in two stages: the elaboration of criteria to evaluate the quality of the alginate wound dressing based on literature; validation of these criteria by a group of evaluators in two moments. Data was analyzed using descriptive statistics, central tendency measures and the Content Validity Index. Results: seven articles were selected, leading to the elaboration of 7 criteria and 11 expected results. The Content Validity Index was 0.98 in stage 1 and 0.93 in stage 2 . After adjustments, 8 criteria were validated, and 13 results were expected. Final Considerations: the study allowed the validation of criteria to evaluate the quality of calcium alginate wound dressings, helping the nurses to choose with more autonomy and assertiveness.

Descriptors: Alginates; Wounds and Injuries; Quality Control; Resource Allocation; Nursing Assessment.

\section{RESUMO}

Objetivos: validar um instrumento com critérios para avaliação da qualidade de coberturas de alginato de cálcio para tratamento de ferida cutânea. Métodos: estudo metodológico, desenvolvido em duas etapas: elaboração de critérios para avaliação da qualidade da cobertura de alginato baseando-se na literatura; validação desses critérios por grupo de juízes em dois momentos. Os dados foram analisados por estatística descritiva, medidas de tendência central e Índice de Validação de Conteúdo. Resultados: selecionaram-se 7 artigos que respaldaram a elaboração de 7 critérios e 11 resultados esperados. O Índice de Validação de Conteúdo foi 0,98 na etapa 1 e 0,93 na etapa 2. Após ajustes, foram validados 8 critérios e 13 resultados esperados. Considerações Finais: o estudo permitiu validar critérios para avaliação da qualidade das coberturas de alginato de cálcio, direcionando a escolha dos enfermeiros com maior autonomia e assertividade. Descritores: Alginato; Feridas; Controle de Qualidade; Gestão de Recursos; Avaliação em Enfermagem.

\section{RESUMEN}

Objetivos: validar un instrumento con criterios para evaluación de la calidad de coberturas de alginato de calcio para tratamiento de herida cutánea. Métodos: estudio metodológico desarrollado en dos etapas: elaboración de criterios para evaluación de la calidad de la cobertura de alginato basándose en la literatura; validación de esos criterios por grupo de jueces en dos momentos. Los datos fueron analizados por estadística descriptiva, medidas de tendencia central e Índice de Validez de Contenido. Resultados: seleccionaron 7 artículos que respaldaron la elaboración de 7 criterios y 11 resultados esperados. El Índice de Validez de Contenido fue 0,98 en la etapa 1 y 0,93 en la etapa 2. Después de ajustes, fueron validados 8 criterios y 13 resultados esperados. Consideraciones Finales: el estudio permitió validar criterios para evaluación de la calidad de las coberturas de alginato de calcio, encaminando la elección de los enfermeros con mayor autonomía y asertividad.

Descriptores: Alginato; Técnicas de Cierre de Heridas; Control de Calidad; Gestión de recursos; Evaluación en Enfermería. 


\section{INTRODUCTION}

Injuries are an important public health problem in Brazil. There is an expressive number of people affected, especially in the elder population ${ }^{(1-2)}$, in addition to the prolonged evolution time ${ }^{(2)}$ and the scarce knowledge many nursing professionals have about the evaluation of injuries and the choice of the proper treatments ${ }^{(3-4)}$.

It stands out that chronic injuries directly interfere in the quality of life of the patients, who deal with the presence of pain, social distancing, and other factors that change their lifestyle and impact daily life activities $s^{(5)}$. In this regard, the nurse has an essential role in the systematized attention and in the treatment of patients with chronic injuries ${ }^{(3-4)}$. Treatment involves not only the anamnesis and physical examination of the patient, but also a minute evaluation of the wound and the choice of wound dressing, according to the needs of each stage of the wound, thus optimizing treatment.

In the clinical practice to treat patients with acute and chronic wounds, there are many types of dressings. Among the most used are the alginate dressings. These are presented in the form of lyophilized sheets (flat and porous) or in tapes and ropes projected for injuries with cavities. It is formed by calcium alginate or sodium and calcium alginate, derived from brown seaweed ${ }^{(6-7)}$.

The main characteristics of calcium alginate are its ability to absorb the exudate of wounds whether they produce it moderately or very intensely; its ability to maintain a wet environment, thus promoting autolytic debridement; and the improvement of the hemostatic capacity due to the calcium ions present in the dressings, which help controlling bleeding ${ }^{(6-7)}$.

Calcium alginate's potential for action is well known, but nurses must have knowledge about the situations in which it is recommended to make proper use of it. However, many professionals do not know which dressings are recommended to treat injuries. A study carried out in Rio de Janeiro, involving 30 nurses from a high-complexity hospital ward, showed that the mean "knowledge" of each nurse about wound dressing recommendations was below $50 \%$. Specifically about calcium alginate, only 10 professionals knew what it was recommended for. This data indicates how uncommon this knowledge is ${ }^{(3)}$.

A study carried out in the Plastic Surgery Division of a university hospital in São Paulo discusses how necessary it is to know, in addition to the functioning mechanism of different dressings, their composition, recommendations, and disadvantages. It also highlights the systematization of "elective" criteria, to select the dressing to improve the conditions of the site of the wound for both its definitive (closing) and intermediate (e.g. preparing for surgery) treatment ${ }^{(8)}$.

The elaboration of systematized criteria on which to base the decisions about wound dressing usage is not limited to the knowledge of the assistance professionals in themselves; it also extends to those who are organizing auctions to buy supplies for health institutions that attend injured patients. This is because, when deciding what product to buy, workers must understand that inadequate use or low-quality materials can be harmful to treatment.

As opposed to laboratory researches on the characteristics of calcium alginate ${ }^{(9-10)}$ dressings, there is a gap in clinical practice when it comes to publications related to criteria to evaluate the performance and quality of these dressings, which could be used to give support to decisions about which dressings health institutions should use and purchase to treat patients with wounds. This led to the issue discussed by this study, according to the guiding question:"What criteria should be considered by nurses, with regard to the evaluation of calcium alginate dressings, at the moment of purchasing these products to treat patients with wounds in clinical practice?".

This study established criteria to evaluate the quality of calcium alginate dressings to give support to the choice of which dressings nurses should purchase in health services, since nurses are, in most cases, responsible for validating, evaluating, and purchasing supplies. Furthermore, these criteria make it possible for these professionals to have specific knowledge, critical reasoning, safety, and autonomy, in addition to subsidies for decision making in the practice of care to patients with injuries, to optimize the treatment of patients who use calcium alginate in a direct and individualized manner.

\section{OBJECTIVES}

To establish and validate criteria to evaluate the quality of alginate wound dressings.

\section{METHODS}

\section{Ethical aspects}

This work was submitted to the appreciation of the Research Ethics Committee from the Universidade Federal de Minas Gerais (UFMG).

\section{Design, period, and place of study}

This is a methodological study. It was developed by the coordinator of two students from the lato sensu post-graduation specialization course in stoma therapy at the nursing school of the Universidade Federal de Minas Gerais; one student from the nursing graduation course; and two students from the stricto sensu post-graduation (MS and PhD). It was carried out from January to June 2020 , in two stages.

\section{Population or sample; criteria for inclusion and exclusion}

In stage 1, literature was reviewed to establish evaluative criteria to evaluate the quality of alginate dressings used to treat injuries. The inclusion criteria adopted were: presenting the characteristics of alginate dressings; being available in full, regardless of free access; being in English, Portuguese, and Spanish; being published from 2012 to 2019. The time frame selected was of seven years, to recover recent articles on the theme, even though there are studies that address alginate dressings since the decade of 1990. Were excluded: book chapters, theses, dissertations, monographs, technical reports, and articles that, after a reading of their abstract, were not in accordance with the study object proposed, in addition to publications that were repeated in the databases and the virtual library.

In stage 2 the criteria and expected results were validated by a committee made up by nine judges, seven nurses and two 
patients. The criteria to include the judges were: professionals who were specialists or had a clinical experience of more than two years in the attention to injured patients, and those inserted in organs of standardization or who participated in the auctioning/purchasing of related supplies. Patients included were those with active or healed wounds and those with experience in the use of calcium alginate in their treatment. The choice of including users as a part of the group of judges was due to the fact that, despite not having academic and scientific knowledge about the theme, they have the knowledge generated by the experience of using the product to treat their own wound, which makes their participation important.

The inclusion criteria were: professionals with conflicts of interest, including those who work in some company or producer of the dressing being analyzed; or researchers who were developing researches whose funding was provided by one of these companies or producers.

\section{Study protocol}

The search for studies, in stage 1, was carried out in the following databases: Cochrane, (Scientific Electronic Library Online), LILACS (Latin American and Caribbean Health Sciences Literature), MEDLINE (National Library of Medicine, EUA), INI (International Nursing Index), CINAHL (Cumulative Index to Nursing and Allied Health Literature), and in the journal platform at CAPES (the Coordination for the Improvement of Higher Education Personnel). The results of the research and selection of studies are presented in Image 1.

In stage 2, the professionals received a form through email, while the patients received in person, due to limitations regarding the Internet. The form included questions about its features (such as age, characterized according to its mean), formation, experience with the dressings, among others, with different questions for professionals and users. Furthermore, it included the expected criteria and results for the evaluation of the quality of calcium alginate dressings.

The judges gave their opinion by classifying each criteria according to a modified Likert scale ${ }^{(17)}$, whose options included: 1) entirely disagree; 2 ) indifferent (or neutral); and 3) totally agree. Furthermore, there was a space for them to insert their comments, observations, and suggestions.

\section{Analysis of results and statistics}

The evaluations of the group of judges were analyzed by the research group at the end of the first phase. After the review and systematization of the changes, the revised proposal was sent again to the judges after 15 days, the second phase of this study. The evaluations of the judges in the second phase followed the same steps as the first one; however, in the revised proposal, there were only the expected criteria and results that had been changed due to comments or suggestions.

Data were analyzed using descriptive statistics and central tendency and dispersion measures, all of which were carried out in the program STATA (version 12.0) for statistical data analysis; in addition to the Content Validity Index (CVI).

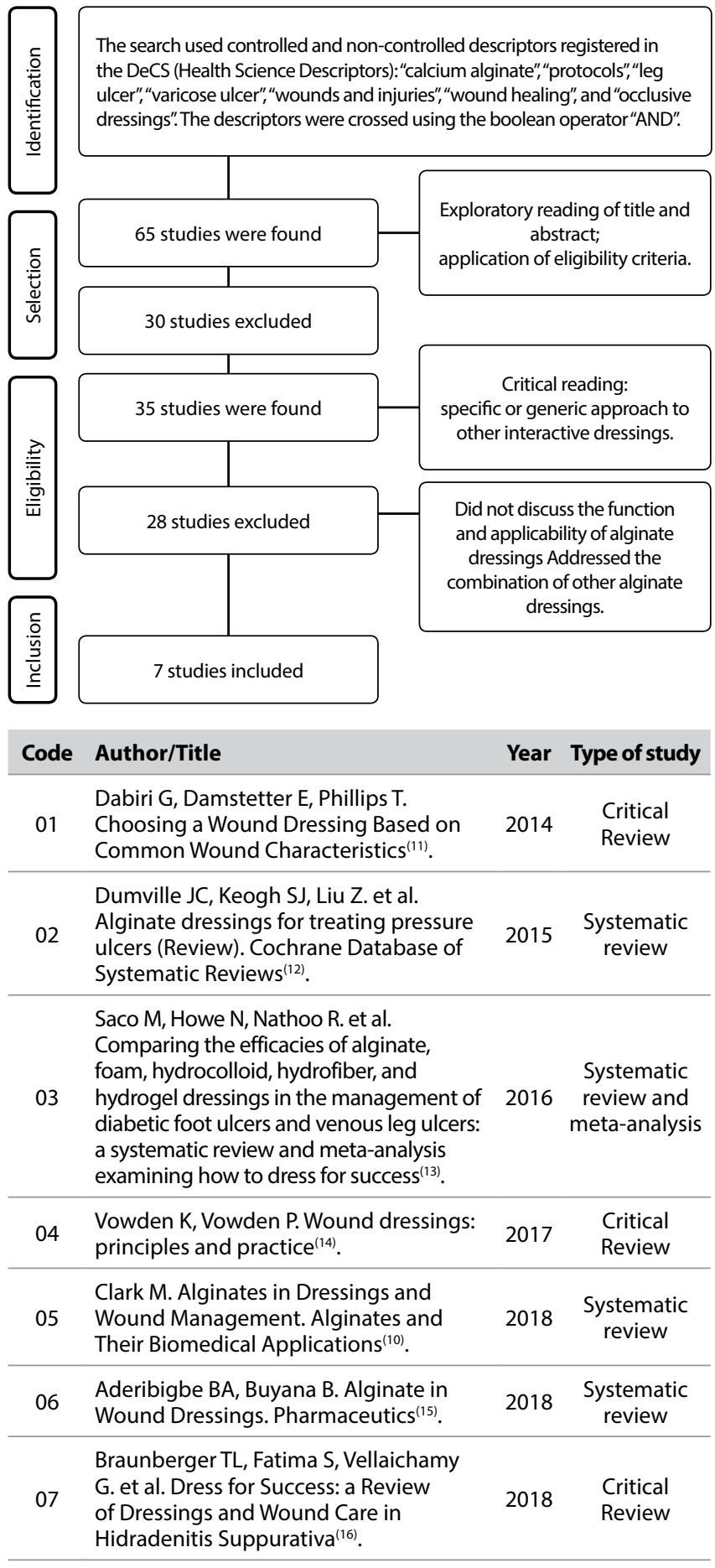

Figure 1 - Flowchart for the selection of the studies to elaborate the evaluation criteria of the quality of the calcium alginate dressing

\section{RESULTS}

In stage 1, seven articles were selected, found in the CAPES journal platform, to create the criteria of quality evaluation of alginate dressings. Among the studies selected, one (14.3\%) of the articles was from 2014, one (14.3\%) was from 2015; one (14.3\%) from 2016; one (14.3\%) from 2017; and three (42.8\%) to 2018. They were codified using the numbers from 1 to 7 . As a result, at first, 7 criteria and 11 expected results were established (Chart 1). 
After the criteria and results expected from the first stage were established, the form was sent to the group of judges formed by five (55.6\%) assistance nurses, in addition to two (22.2\%) nurses from the auction/purchasing sector and two (22.2\%) patients attended in health services, who represented the users. The mean age of the participants was 42 years old (minimum of 33 and maximum of 59 years old; SD 8.8; Cl 95\%). In regard to the service in which they work or are attended, seven $(77.8 \%$ mentioned the public sector, while $22.2 \%$ mentioned the private network). When asked about the importance of an instrument to evaluate the importance of interactive dressings, nine judges (100\%) answered that it was very important.

All professionals were nurses, graduated from 2003 to 2008 , with a mean of 14 years working in nursing (SD 0.91; Cl 95\%; minimum of 11 and maximum of 17 years); the mean time they had worked with wound treatment/interactive dressings was 10 years (SD 1.49; Cl 95\%, minimum of 4 and maximum of 16 years). Three (42.9\%) had an MS.
From the two (22.2\%) judges who were users, one had incomplete elementary education and another complete high school; one was on leave from work, and another was self-employed; both had had a venous wound from three to five years, respectively. Both state that the existence of a standardized instrument to evaluate interactive wound dressings can bring benefits to their treatment.

In the first evaluation, all judges entirely agreed to the following criteria: exudate absorption, comfort, wound hemostasis, hypoallergenic, integrity, the filling-in of dead space, and non-traumatic removal from the wound - an exception was made to the criterion wound hemostasis, about which one of the judges was indifferent, presenting a justification for this response. Regarding the expected results about this criterion, one of the judges gave no opinion (Table 1). There was a proposal to add one criterion, the autolytic debridement, and its respective expected result. The CVI of the first stage of evaluation by the judges was 0.98 , showing a high level of agreement between evaluators.

Chart 1 - Relation of evaluation criteria of the quality of alginate dressings and expected results - $(n=18)$, Belo Horizonte, Minas Gerais, Brazil, 2020

\begin{tabular}{|c|c|c|c|}
\hline \multirow{2}{*}{ Criterion } & \multicolumn{2}{|r|}{ Source of information } & \multirow{2}{*}{ Expected result } \\
\hline & Code & Author/Year & \\
\hline \multirow{4}{*}{$\begin{array}{l}\text { 1) Non-traumatic } \\
\text { removal of the } \\
\text { injury }\end{array}$} & 01 & Dabiri G, Damstetter E, Phillips T. 2014 $4^{(11)}$ & \multirow{4}{*}{$\begin{array}{l}\text { 1. Absence of adherence of the dressing in the site of the } \\
\text { injury at the moment of its removal. } \\
\text { 2. Absence of trauma (pain/bleeding) after removal. }\end{array}$} \\
\hline & 02 & Dumville JC, Keogh SJ, Liu Z. et al. $2015^{(12)}$ & \\
\hline & 05 & Clark M. $2018^{(10)}$ & \\
\hline & 06 & Aderibigbe BA, Buyana B. $2018^{(15)}$ & \\
\hline \multirow{7}{*}{$\begin{array}{l}\text { 2) Exudate } \\
\text { absorption }\end{array}$} & 01 & Dabiri G, Damstetter E, Phillips T. 2014 $4^{(11)}$ & \multirow{7}{*}{ 1. Gelatinous aspect at the moment of removal. } \\
\hline & 02 & Dumville JC, Keogh SJ, Liu Z. et al. 2015(12) & \\
\hline & 03 & Saco M, Howe N, Nathoo R. et al. $2016^{(13)}$ & \\
\hline & 04 & Vowden K, Vowden P. $2017^{(14)}$ & \\
\hline & 05 & Clark M. $2018^{(10)}$ & \\
\hline & 06 & Aderibigbe BA, Buyana B.2018 ${ }^{(15)}$ & \\
\hline & 07 & Braunberger TL, Fatima S, Vellaichamy G. et al. $2018^{(16)}$ & \\
\hline \multirow{5}{*}{$\begin{array}{l}\text { 3) Wound } \\
\text { hemostasis }\end{array}$} & 01 & Dabiri G, Damstetter E, Phillips T. 2014 ${ }^{(11)}$ & \multirow{5}{*}{$\begin{array}{l}\text { 1. Being capable of interrupting small bleedings, inducing the } \\
\text { formation of coagulation, with no further bleeding at removal. }\end{array}$} \\
\hline & 04 & Vowden K, Vowden P. 2017(14) & \\
\hline & 05 & Clark M. $2018^{(10)}$ & \\
\hline & 06 & Aderibigbe BA, Buyana B. $2018^{(15)}$ & \\
\hline & 07 & Braunberger TL, Fatima S, Vellaichamy G. et al. $2018^{(16)}$ & \\
\hline \multirow{4}{*}{$\begin{array}{l}\text { 4) Filling-in of } \\
\text { dead space }\end{array}$} & 03 & Saco M, Howe N, Nathoo R. et al. $2016^{(13)}$ & \multirow{4}{*}{$\begin{array}{l}\text { 1. Being able to fill in the cavity/depth; fitting in the space of the } \\
\text { wound without provoking trauma as it is introduced. } \\
\text { 2. Not disintegrating or dissolving at the moment it is } \\
\text { introduced in the cavity/depth of the wound. } \\
\text { 3. Not disintegrating or dissolving at the moment of removal } \\
\text { from the cavity/depth of the wound. }\end{array}$} \\
\hline & 04 & Vowden K, Vowden P. 2017 $7^{(14)}$ & \\
\hline & 05 & Clark M. $2018^{(10)}$ & \\
\hline & 07 & Braunberger TL, Fatima S, Vellaichamy G. et al. $2018^{(16)}$ & \\
\hline \multirow{3}{*}{ 5) Comfortable } & 01 & Dabiri G, Damstetter E, Phillips T. 2014 $4^{(11)}$ & \multirow{3}{*}{$\begin{array}{l}\text { 1. Pain does not continue, when it presents itself, after } 30 \text { to } 40 \\
\text { minutes at the site of the wound*. } \\
\text { *Time needed for the temperature and physiological humidity } \\
\text { to return. }\end{array}$} \\
\hline & 02 & Dumville JC, Keogh SJ, Liu Z. et al. $2015^{(12)}$ & \\
\hline & 03 & Saco M, Howe N, Nathoo R. et al. $2016^{(13)}$ & \\
\hline \multirow{3}{*}{ 6) Integrity } & 01 & Dabiri G, Damstetter E, Phillips T. 2014(11) & \multirow{3}{*}{$\begin{array}{l}\text { 1. Remaining intact (not disintegrating, tearing) when applied } \\
\text { to the site of the lesion. } \\
\text { 2. Not leaving residue at the site of the lesion upon removal. }\end{array}$} \\
\hline & 03 & Saco M, Howe N, Nathoo R. et al. $2016^{(13)}$ & \\
\hline & 05 & Clark M. $2018^{(10)}$ & \\
\hline \multirow[b]{2}{*}{ 7) Hypoallergenic } & 03 & Saco M, Howe N, Nathoo R. et al. $2016^{(13)}$ & \multirow{2}{*}{$\begin{array}{l}\text { 1. Triggering the minimal number of possible reactions, a } \\
\text { proportion of } 1: 100 \text { patients. When used in patients with } \\
\text { a history of allergies (to other products), the proportion of } \\
\text { allergic reactions cannot reach } 2: 100 \text { patients. }\end{array}$} \\
\hline & 06 & Aderibigbe BA, Buyana B. $2018^{(15)}$ & \\
\hline
\end{tabular}


Although there was a high level of agreement between the judges, three suggestions and three comments were made, especially from those who did not disagree from any item nor were indifferent to any of them. The comments and suggestions involved discussing about the writing of the content or, specifically, about complementary functions of the dressing that were not considered by the instrument.

Therefore, even though the judges completely agree, their comments and suggestions were considered after a critical discussion and analysis by researchers. This was done in consideration for the experience and competence of these judges in the use or purchasing of alginate dressings. After the alterations, only the criteria and expected results that were changed were sent again, in the second stage, for another appreciation of the judges (Table 2).

One of the judges was indifferent to the criteria added, Autolytic Debridement, while another completely disagreed from the expected results proposed for the criteria Exudate Absorption. The CVI of the second stage was 0.93 , indicating that the agreement among evaluators was still high.

After the second moment of stage 2, no comment or suggestion was made, thus completing the elaboration of the instrument (Chart 2).

Table 1 - Frequency of agreement between the judges about the expected criteria and results for the evaluation of the quality of alginate dressings $(n=9)$, Belo Horizonte, Minas Gerais, Brazil, 2020

\begin{tabular}{|c|c|c|c|}
\hline Criteria & $\begin{array}{l}\text { Completely } \\
\text { agree } \\
n(\%)\end{array}$ & Expected result & $\begin{array}{l}\text { Completely } \\
\text { agree } \\
n(\%)\end{array}$ \\
\hline Non-traumatic removal of the injury & $9(100.0)$ & $\begin{array}{l}\text { 1. Absence of adherence of the dressing in the site of the injury at the moment of its removal. } \\
\text { 2. Absence of trauma (pain/bleeding) after removal. }\end{array}$ & $\begin{array}{l}9(100.0) \\
9(100.0)\end{array}$ \\
\hline Exudate absorption & $9(100.0)$ & 1. Gelatinous aspect at removal. & $9(100.0)$ \\
\hline Wound hemostasis & $8(88.9)$ & $\begin{array}{l}\text { 1. Being able of interrupting small bleedings, inducing coagulation, and not presenting } \\
\text { further bleeding at removal. }\end{array}$ & $8(88.9)$ \\
\hline Filling-in of dead space & $9(100.0)$ & $\begin{array}{l}\text { 1. Being able to fill in the cavity/depth; fitting in the space of the wound without } \\
\text { provoking trauma as it is introduced. } \\
\text { 2. Not disintegrating or dissolving when introduced in the cavity/depth of the wound. } \\
\text { 3. Not disintegrating or dissolving when removed from the cavity/depth of the wound. }\end{array}$ & $\begin{array}{l}9(100.0) \\
9(100.0) \\
9(100.0)\end{array}$ \\
\hline Comfort & $9(100.0)$ & $\begin{array}{l}\text { 1. Pain that does not continue, when it presents itself, after } 30 \text { to } 40 \text { minutes at the site of } \\
\text { the wound (time needed for the temperature and physiological humidity to return). }\end{array}$ & $9(100.0)$ \\
\hline Integrity & $9(100.0)$ & $\begin{array}{l}\text { 1. Remaining intact (not disintegrating, tearing) when applied to the site of the lesion. } \\
\text { 2. Not leaving residue at the site of the lesion upon removal. }\end{array}$ & $\begin{array}{l}9(100.0) \\
9(100.0)\end{array}$ \\
\hline Hypoallergenic & $9(100.0)$ & $\begin{array}{l}\text { 1. Triggering the minimal number of possible reactions, a proportion of 1:100 patients. } \\
\text { When used in patients with a history of allergies (to other products), the proportion of } \\
\text { allergic reactions cannot reach } 2: 100 \text { patients. }\end{array}$ & $9(100.0)$ \\
\hline
\end{tabular}

Table 2 - Evaluation by the judges of the criteria and expected results added or changed from the instrument of criteria for alginate dressings $-(\mathrm{n}=$ 9), Belo Horizonte, Minas Gerais, Brazil, 2020

\begin{tabular}{|c|c|c|c|}
\hline Criterion & $\begin{array}{c}\text { Completely } \\
\text { agree }\end{array}$ & Expected result & $\begin{array}{c}\text { Completely } \\
\text { agree }\end{array}$ \\
\hline Exudate absorption ${ }^{i}$ & $9(100)$ & $\begin{array}{l}\text { 1. Presenting gelatinous aspect at removal and not causing macerations in the surrounding skint. } \\
\text { 2. Maintaining absorption capabilities for at least } 48 \text { hours, having a wound with moderate } \\
\text { exudate as a reference point } £ \text {. }\end{array}$ & $8(88.9)$ \\
\hline Wound hemostasisi & $9(100)$ & $\begin{array}{l}\text { 1. Being capable of interrupting small bleedings that result from the trauma in micro-vessels, } \\
\text { inducing coagulation and not presenting further bleeding at removal.i Not appropriate for the } \\
\text { hemostasis of more pronounced bleedingst. }\end{array}$ & $9(100)$ \\
\hline Autolytic debridement ${ }^{\ddagger}$ & $8(88.9)$ & 1. Promoting the reduction of necrotic tissue by slough in up to 15 days of wound treatment & $8(88.9)$ \\
\hline
\end{tabular}

Chart 2 - Final list of criteria and expected results for the evaluation of the quality of alginate dressings, Belo Horizonte, Minas Gerais, Brazil, 2020

\begin{tabular}{|l|l|}
\hline \multicolumn{1}{|c|}{ Criterion } & Expected result \\
\hline $\begin{array}{l}\text { 1) Non-traumatic removal } \\
\text { of the injury }\end{array}$ & $\begin{array}{l}\text { 1. The dressing does not adhere to the site of the injury at the moment of removal. } \\
\text { 2. No trauma (pain/bleeding) after removal. }\end{array}$ \\
\hline 2) Exudate absorption & $\begin{array}{l}\text { 1. Presenting a gelatinous aspect at the moment of removal. } \\
\text { 2. Maintaining absorption capabilities for at least } 48 \text { hours, having a wound with moderate exudate as a reference point. }\end{array}$ \\
\hline 3) Wound hemostasis & $\begin{array}{l}\text { 1. Being capable of interrupting small bleedings that result from the trauma in micro-vessels, inducing coagulation } \\
\text { and not presenting further bleeding at removal. Not appropriate for the hemostasis of more pronounced bleedings. }\end{array}$ \\
\hline 4) Filling-in of dead space & $\begin{array}{l}\text { 1. Being able to fill in the cavity/depth and fitting in the space of the wound without provoking trauma as it is introduced. } \\
\text { 2. Not disintegrating or dissolving at the moment it is introduced in the cavity/depth of the wound. } \\
\text { 3. Not disintegrating or dissolving at the moment of removal from the cavity/depth of the wound. }\end{array}$ \\
\hline
\end{tabular}


Chart 2 (concluded)

\begin{tabular}{|l|l|}
\hline \multicolumn{1}{|c|}{ Criterion } & Expected result \\
\hline 5) Comfort & $\begin{array}{l}\text { 1. Pain that does not continue, if it presents itself, after } 30 \text { to } 40 \text { minutes at the site of the wound* } \\
\text { *Time needed for the temperature and physiological humidity to return. }\end{array}$ \\
\hline 6) Integrity & $\begin{array}{l}\text { 1. Remaining intact (not disintegrating, tearing) when applied to the site of the lesion. } \\
\text { 2. Not leaving residue at the site of the lesion upon removal. }\end{array}$ \\
\hline 7) Hypoallergenic & $\begin{array}{l}\text { 1. Triggering the minimal number of reactions, a proportion of 1:100 patients. When used in patients with a history of } \\
\text { allergies (to other products), the proportion of allergic reactions cannot reach 2:100 patients. }\end{array}$ \\
\hline 8) Autolytic debridement & 1. Promoting the reduction of necrotic tissue by slough in up to 15 days of wound treatment. \\
\hline
\end{tabular}

\section{DISCUSSION}

This study was validated through an evaluation by nurses who worked for a mean of 10 days in auctioning/purchasing and clinical use of alginate dressings and by patients who were treated using this dressing. Considering the expertise of these judges and the pertinence of their suggestions and comments, despite of a high agreement, all alterations suggested were implemented, especially because they were relevant regarding the clarity of the criteria or expected results, or would complement that which had been established by the instrument.

It stands out that, in validation studies, the items being evaluated must be judged by people with expertise in the field/theme in which the instrument or technology created can be applied, since they are responsible for judging whether the variables of this instrument attend or not to the objective they aim to attend ${ }^{(18)}$. Therefore, the experience of the professionals who evaluate the pertinence, validity, and adequation of an instrument is essential, and contributes substantially for a better understanding, clarity, reliability, and applicability of this instrument in validations ${ }^{(19)}$.

In this regard, the justification of the criteria Wound Hemostasis is related to the first stage of the evaluation in this study. One of the judges commented that the alginate is used incorrectly for this end in clinical practice, since many professionals use it to interrupt large bleedings. As a result, there was a suggestion aimed to include clarifications, in the expected results, about the fact that the hemostatic function of the alginate should only be used for small bleedings.

The hemostatic function of the alginate results from the action of the calcium ions $(\mathrm{Ca}+)$. When it touches the wound, there is an active release of these ions, which are a natural co-factor in the process of bleeding coagulation, and can be recommended after, for instance, debridement or biopsies ${ }^{(20)}$. However, it should be considered that this function applies to small wounds, and is not recommended for large bleedings, which may require surgical intervention and must be critically evaluated by the medical team.

Another feature of the alginate is its gelation capability. Once it touches the wound, there is an interaction between the (calcium or sodium) ions in the dressing and in the exudate. As a result, the alginate assumes a gel-like aspect, which is partly due to its high absorption capabilities ${ }^{(20)}$. This gelation of the matrix of the alginate means it has the function of retaining residues in the wound. Among them, there are bacterial products and fibrin, which, when removed, cause autolytic debridement ${ }^{(21)}$.

The capacity for autolytic debridement was the suggestion of one of the judges, since it was not included in the first version of the instrument. As a result, it was added in the second stage of the study, considering it may happen in clinical practice. It should be mentioned that, although the alginate is presented in other forms - as in combinations with hydrogels, collagen, alginate with sodium ions, alginate film, and others - that this study focuses on alginate as presented in films, sheets, and ropes, since these are the most common in the clinical practice of nurses in Brazil.

Regarding the high absorption capacity of the alginate, it is contraindicated for wounds with little exudation or bedsore necrotic tissue, since it is not a selective dressing, that is, it can absorb all aqueous components from the site of the wound, dehydrating it when the humidity is low ${ }^{(21)}$, leaving behind a dry environment that is not conducive to healing.

Another important aspect is that, when there is no exudate or it is insufficient for the formation of the gel, removing the dressing becomes difficult due to the generally fibrous composition of the alginate, that is, residual fibers can be left in the wound, triggering inflammatory responses ${ }^{(20)}$. When this happens, the chances for trauma at the site of the lesion increase at the time of changing the dressing.

As a result, the changes suggested by the judges were pertinent, and the adjustments were carried out considering their justifications and literary bases. It is important to highlight that none of the judges knew of any instrument that had criteria to help their evaluation of dressings. They were also unanimous in stating that the existence of such an instrument is extremely important.

Few studies evaluate the clinical quality of interactive dressings. However, those who validate instruments for the clinical evaluation of wounds emphasize that the quality of the assistance provided to patients with wounds depends on the training of the workers and on the systematization of standardized protocols or instruments to guide decision making, both in treatment and for preventive or diagnostic purposes ${ }^{(22)}$. The subjective perception of each nurse about the evaluation of a wound can lead to different interpretations, considering that the knowledge of the nurses who provide care varies, which indicates the relevance of these training sessions and instruments.

These explanations, however, can be extended to the evaluation of quality criteria of interactive dressings. Many workers, despite having a broad experience, have different knowledge and know of a large variety of producers and suppliers of these dressings, which often present with new technologies, different costs, and competition in auctions.

The large supply and the wide variety of possibilities, added to the perspective these presentations provide for healing, can lead the nurse to become insecure at the moment of choosing, acquiring, and using the product. This shows the importance of a standardized instrument, based on specific literature and judged 
by professionals who are specialists in the field, to give support to the nurses as they purchase these supplies to treat wounds.

This study is expected to give support to the decision making of nurses regarding the evaluation of the quality of the calcium alginate dressings before their acquisition by the health services and use in the patient. As a result, this work is expected to contribute directly or indirectly to the autonomy of these professionals, minimizing the chances of choosing a product with inadequate characteristics, and aiming to guarantee the safety of the patients, in addition to improving the quality of the assistance provided.

\section{Limitations and perspectives of the study}

At first, the data collection for this research was scheduled to take place in-person. However, due to the current pandemic of the new coronavirus (COVID-19), some adaptations were in order. It was essential to use virtual and electronic means to acquire the data and discussions of relevant topics for the research. This require the team to innovate through the use of an online medium; however, it interfered, directly or not, in the time it took to carry out the research and made it impossible for the judges to participate in a focal group or for data collection to be made in person.

Another important limitation, also related to the COVID-19 pandemic, was the fact that some judges had difficulties in accessing virtual platforms, and took long to give the instruments back, especially due to the fact that some of them were working in the front lines of the struggle against the pandemic, and this study took place at a period in which the number of COVID-19 cases in the state of Minas Gerais was increasing. The perspectives of this study include: a better knowledge about the features of calcium alginate dressings; the possibility that this instrument can direct the nurses, helping to make safe choices at the moment evaluating and purchasing this material.

\section{Contributions to the fields of Nursing, Health or Public Policy}

This study contributes for the autonomy of the nursing professionals regarding the evaluation, choice, purchasing, and use of alginate dressings in the health services that treat wounded patients, regardless of etiology. Furthermore, it enables a quality management of these dressings, aided by evaluative criteria. It also allows for the management of resources, which minimize the consumption of low-quality materials for the treatment of wounds and thus improves the definition of expenses, guaranteeing that patient and health services make cost-effective decisions.

\section{CONCLUSIONS}

The instrument of criteria to evaluate the quality of calcium alginate dressings was validated by a group of judges who were experts in the use, and auctioning/purchasing of this material. This tool gives support for nurses who work in the treatment of wounds to purchase these dressings, providing them with autonomy and assertiveness with regard to the treatment.

This work is pioneer in approaching the theme of validation of the criteria to evaluate the quality of interactive dressings. It is expected to contribute for future researches, since this type of study is extremely important for clinical practice.

\section{REFERENCES}

1. Duim E, Sá FHC, Duarte YAO, Oliveira RCB, Lebrão ML. Prevalência e características das feridas em pessoas idosas residentes na comunidade. Rev Esc Enferm USP. 2015;49(spe):51-7. https://doi.org/10.1590/S0080-623420150000700008

2. Vieira CPB, Araújo TME. Prevalência e fatores associados a feridas crônicas em idosos na atenção básica. Rev Esc Enferm USP. 2018 [cited 2020 May 11];52:e03415. https://doi.org/10.1590/S1980-220X2017051303415

3. Prado ARA, Barreto VPM, Tonini T, Silva AS, Machado WCA. O saber do enfermeiro na indicação de coberturas no cuidado ao cliente com feridas. Estima. 2016;14(4):175-82. https://doi.org/10.5327/Z1806-3144201600040004

4. Colares C, Luciano C, Neves H, Tipple A, Galdino Jr H. Cicatrização e tratamento de feridas: a interface do conhecimento à prática do enfermeiro. Enferm Foco. 2019;10(3). https://doi.org/10.21675/2357-707X.2019.v10.n3.2232

5. Oliveira AC, Rocha DM, Bezerra SMG, Andrade EMLRE, Santos AMRA, Nogueira LT. Qualidade de vida de pessoas com feridas crônicas. Acta Paul Enferm. 2019;32(2):194-201. https://doi.org/10.1590/1982-0194201900027

6. Gupta BS, Edwards JV. Textile materials and structures for topical management of wounds. Adv Text Wound Care. 2019;55-104. https://doi. org/10.1016/b978-0-08-102192-7.00003-5

7. O'Meara S, Martyn-St James M, Adderley UJ. Alginate dressings for venous leg ulcers. Cochrane Database System Rev. 2015;8(CD010182). https://doi.org/10.1002/14651858.CD010182.pub3

8. Smaniotto PHS, Ferreira MC, Isaac C, Galli R. Sistematização de curativos para o tratamento clínico das feridas. Rev Bras Cir Plást. 2012;27(4):623-6. https://doi.org/10.1590/S1983-51752012000400026

9. Hoefer D, Schnepf JK, Hammer, TR, Fischer M, Marquardt C. Biotechnologically produced microbial alginate dressings show enhanced gel forming capacity compared to commercial alginate dressings of marine origin. J Materials Sci: Mat Med. 2015;26(4). https://doi.org/10.1007/ s10856-015-5492-5

10. Clark M. Alginates in dressings and wound management: alginates and their biomedical applications. 2017;213-22. https://doi. org/10.1007/978-981-10-6910-9_8

11. Dabiri G, Damstetter E, Phillips T. Choosing a wound dressing based on common wound characteristics. Adv Wound Care. 2014;5(1):1-10. https://doi.org/10.1089/wound.2014.0586 
12. Dumville JC, Keogh SJ, Liu Z. Stubbs N, Walker RM, Fortnam M. Alginate dressings for treating pressure ulcers: review. Cochrane Database System Rev. 2015;5(CD011277):1-57. https://doi.org/10.1002/14651858.CD011277.pub2

13. Saco M, Howe N, Nathoo R, Cherpelis B. Comparing the efficacies of alginate, foam, hydrocolloid, hydrofiber, and hydrogel dressings in the management of diabetic foot ulcers and venous leg ulcers: a systematic review and meta-analysis examining how to dress for success. Dermatol O J [Internet]. 2016 [cited 2020 May 3];22(8):3-17. Available from: https://escholarship.org/uc/item/7ph5v17z

14. Vowden K, Vowden P. Wound dressings: principles and practice. Surgery. 2017;1-6. https://doi.org/10.1016/j.mpsur.2017.06.005

15. Aderibigbe BA, Buyana B. Alginate in Wound Dressings. Pharmaceutics. 2018;10(42):1-19. https://doi.org/10.3390/pharmaceutics10020042

16. Braunberger TL, Fatima S, Vellaichamy G, Nahhas AF, Parks-Miller A, Hamzavi IH. Dress for success: a review of dressings and wound care in hidradenitis suppurativa. Current Dermatol Rep. 2018;9p. https://doi.org/10.1007/s13671-018-0231-z

17. Fialho FA, Dias IMAV, Rego MPCMA. Instrumento de coleta de dados quantitativos em pesquisa de bioética realizada com crianças. Tempus Actas Saúde Colet. 2005;9(3):179-86. https://doi.org/10.18569/tempus.v9i3.1795

18. Medeiros RKS, Ferreira Jr MA, Pinto DPSR, Vitor AF, Santos VEP, Barichello E. Modelo de validação de conteúdo de Pasquali nas pesquisas em Enfermagem. Rev Enf Ref. 2015;(4):127-35. https://doi.org/10.12707/RIV14009

19. Tibúrcio MP, Melo GSM, Balduíno LSC, Costa IKF, Dias TYAF, Torres GV. Validação de instrumento para avaliação da habilidade de mensuração da pressão arterial. Rev Bras Enferm. 2014;67(4):581-7. https://doi.org/10.1590/0034-7167.2014670413

20. Weller C, Team V. Interactive dressings and their role in moist wound management. In Rajendran S (ed.) Advanced Textiles for Wound Care. 2nd ed. United Kingdom: Woodhead Publishing Limited. 2019;105-34. https://doi.org/10.1016/B978-0-08-102192-7.00004-7

21. Janowska A, Macchia M, Paggi B. Advanced Dressings in Pressure Ulcers. Springer-Verlag London Ltd., part of Springer Nature. In: Romanelli M, (Ed.). Science and Practice of Pressure Ulcer Management. 2018;159-73. https://doi.org/10.1007/978-1-4471-7413-4_12

22. Costa RKS, Torres GV, Salvetti MG, Azevedo IC, Costa MAT. Validity of instruments used in nursing care for people with skin lesions. Acta Paul Enferm. 2014;27(5):447-57. https://doi.org/10.1590/1982-0194201400074

23. Bajay HM, Araújo IEM. Validação e confiabilidade de um instrumento de avaliação de feridas. Acta Paul Enferm. 2006;19(3):290-5. https://doi. org/10.1590/S0103-21002006000300006 